\title{
Evaluation of Arbuscular Mycorrhizal Fungi and Trichoderma Species for the Control of Onion White Rot (Sclerotium cepivorum Berk)
}

Ararsa Leta and Thangavel Selvaraj*

Department of Plant Sciences and Horticulture, College of Agriculture and Veterinary Sciences, Ambo University, Ambo, P.O. Box 19, Ethiopia

\begin{abstract}
The present study was carried out to evaluate the indigenous Arbuscular Mycorrhizal Fungi (AMF) and Trichoderma species isolated from rhizosphere soils of onion cultivated fields at Ambo and Toke Kutaye districts of West Showa, Ethiopia, and their effect on plant growth, and their biocontrol against onion white rot caused by Sclerotium cepivorum Berk. Five species with twenty isolates of Trichoderma were isolated and screened in vitro for the inhibition of S. cepivorum. Out of these, four isolates of Trichoderma spp viz. T. harzianum (ATh1), T. viride (ATv1), T. hamatum (NThm3), and T. koningii (QTk2), were found potent antagonists with mean percent inhibition of the pathogen, 65.4, 64.8, 54.3 and 53.5, respectively. Altogether, 10 AMF species representing four genera viz. Acaulospora, Gigaspora, Glomus, and Scutellospora, were isolated and identified. Six dominant species of AMF were selected and mass multiplied by using Sorghum vulgare Pers. as the compatible host plant. Among six AMF species, the potential efficient strain, Glomus aggregatum (Awaro isolate), was selected for using as bio control agent. The bio-control potential of these bio-agents against white rot pathogen was carried out under pot culture condition, using G. aggregatum alone or in combination with four isolates of Trichoderma spp. Incidence of S. cepivorum was significantly reduced in bulbs of onion $(66.19 \%)$, and also improved plant growth was observed in plants inoculated with combined inoculation of G. aggregatun and T. harzianum (ATh1 isolate), followed by the combined inoculation of G. aggregatum and T. viride (ATv1) with pathogen (59.75\%). Plants inoculated with S. cepivorum alone showed pronounced disease symptoms with mean disease incidence of $90.5 \%$. The overall reduction in the incidence of white rot was $56.22 \%$ in the treatment of $T$. harzianum ATh1 isolate with pathogen, followed by $53.72 \%$ for $G$. aggregatum with pathogen. These results clearly pointed out that G. aggregatum and T. harzianum ATh1 isolate can block the severity of disease caused by $S$. cepivorum in onion. Use of these bio-control agents could be promoted as an active component of bio-intensive Integrated Disease Management Program (IDMP), under organic mode.
\end{abstract}

Keywords: Arbuscular mycorrhizal fungi; Trichoderma spp.; Biocontrol; Onion; White rot; Sclerotium cepivorum

\section{Introduction}

Allium crops are the most indispensable vegetable crops used as condiments in most Ethiopian cuisine. Among them, onion (Allium cepa L.), rightly called as "queen of kitchen", is one of the oldest known and an important bulbous vegetable crop grown in Ethiopia. It is used in preparation of different foods, and in therapeutic medicine in the country. Besides, it is rich in flavonoids like quercetin and sulfur compounds, such as allylpropyl disulphide, that have been perceived benefits to human health [1]. Onion has also medicinal value, as a possible cancer preventive $[2,3]$. The best growing altitude for onions under Ethiopian condition is between 700 and 1800 MASL (Meters Above Sea Level) [4]. A survey made in 1987 estimated the total area under onions and shallot in Ethiopia to be about 10,000 ha, with the total production of about 75-500 tones. But, now-a-days the area under the production of onion is increased by far and productivity also increased up to $80-120 \mathrm{~kg} / \mathrm{ha}$ under optimum condition [4]. However, the productivity of onion is affected by many biotic and abiotic stresses, resulting in yield reduction, low quality and less storability of the crop, and other constraints in the production of onion in Ethiopia, including the use of low quality seeds, imbalanced fertilizers, and uneven irrigations.

Among the diseases of onion, white rot (Sclerotium cepivorum Berk.) is identified as the most important disease of onion in Ambo and Toke Kutaye districts of West Showa, Ethiopia, causes breaking of floral stalks, and thus, the bulb yield and seed production is significantly reduced. In Ethiopia, the management methods of the diseases of onion are followed as mainly crop rotation, avoidance and sanitation to proper storage methods [5]. Conventional methods of control of diseases of onion include the use of chemicals, organic means, and through integrated management efforts. As a result, attempts to manage the disease have focused on reducing the populations of sclerotia in the soil through biological control. Research on biological control of plant pathogens has received much attention in recent years, as a means of increasing crop production by avoiding a number of problems related to chemical control, and hence, developing practices compatible with sustainable agriculture [6].

Arbuscular mycorrhizal fungi (AMF) are widespread in nature, and a fundamental component of agro ecosystems. AM symbioses may also improve plant health through a more specific increase in protection (improve resistance, and/or tolerance against biotic and abiotic stresses) [7,8]. Trichoderma spp. as a potential bio control agent was recognized in the early 1930's [9]. Among different strategies for plant growth promotion and disease suppression, biological approaches are very useful, and an ominous choice. The use of AMF and an antagonistic fungus, Trichoderma spp. are the major players,

*Corresponding author: Prof. Thangavel Selvaraj, Department of Plant Sciences and Horticulture, College of Agriculture and Veterinary Sciences, Ambo University, Ambo, P.O. Box 19, Ethiopia, Tel: +251-913073294; Fax: +251-112362037; E-mail: tselvaraj_1956@yahoo.com

Received December 07, 2012; Accepted January 21, 2013; Published January 26,2013

Citation: Leta A, Selvaraj T, (2013) Evaluation of Arbuscular Mycorrhizal Fungi and Trichoderma Species for the Control of Onion White Rot (Sclerotium cepivorum Berk). J Plant Pathol Microb 4: 159. doi:10.4172/2157-7471.1000159

Copyright: (c) 2013 Leta A, et al. This is an open-access article distributed under the terms of the Creative Commons Attribution License, which permits unrestricted use, distribution, and reproduction in any medium, provided the original author and source are credited. 
which could play active role in plant growth promotion and disease suppressions. Attempts have been made to know the importance of white rot disease on some onion growing areas, but not much detailed studies on disease survey works have been carried out, particularly in Ambo and Toke Kutaye districts of West Showa, Ethiopia. Hence, the present study was carried out to evaluate the native strains of AMF and Trichoderma spp. isolated from rhizosphere soils of onion cultivated fields at Ambo and Toke Kutaye districts of West Showa, Ethiopia, and their effect on plant growth promotion, and biological control activities against white rot disease.

\section{Materials and Methods}

\section{Description of the study areas}

The screening experiment was conducted in Ambo and Toke Kutaye districts of West Showa zone, Oromia Regional State, Ethiopia, during the academic year, 2008-2009, to evaluate the indigenous AMF and Trichoderma species from rhizosphere soils of onion cultivated fields at Awaro and Qora from Ambo district, and Nagafile and Imala Dawe (I/D) Ajo from Toke Kutaye district of West Showa, Ethiopia. Ambo district has total geographical area of 83598.69 sq.kms, which is located at $8^{\circ} 57^{\prime}$ North latitude and $38^{\circ} 07^{\prime}$ East longitude, at an average elevation of 1380-3300 meter above the sea level, and the Toke Kutaye district has total geographical area of 78887 sq.kms and is located at $8^{\circ} 57^{\prime}$ North latitude and $38^{\circ} 07^{\prime}$ East longitude, at an average elevation of 1800-2300 meter above the sea level. In both districts, the annual rainfall ranged from $800-1000 \mathrm{~mm}$ and the temperature of the districts ranged between $15^{\circ} \mathrm{C}$ and $29^{\circ} \mathrm{C}$, with average temperature of $22^{\circ} \mathrm{C}$.

\section{Sample collection}

The soil and root samples were collected from four different onion cultivated field study sites. At each study site, an area of 500 sq. meters was chosen for sampling. Five healthy and diseased plants were selected, and their roots, bulbs and rhizosphere soil samples were collected at $0-30 \mathrm{~cm}$ soil depth. Approximately, $2 \mathrm{~kg}$ of rhizosphere soil was collected in triplicates from each study site, and the samples were brought to Ambo Plant Protection Research Center (APPRC) laboratory in sealed plastic bags, and stored at $5-10^{\circ} \mathrm{C}$. The roots of the healthy test plants were separately washed thoroughly, free of attached soil particles, and cut in to $1 \mathrm{~cm}$ bits and fixed in Formalin: Acetic acid: Alcohol (FAA) in the field itself [10]. The diseased bulbs were collected from the field in sealed plastic bags and stored at $5-10^{\circ} \mathrm{C}$, until processed for use. Soil samples were thoroughly mixed and a portion of soil samples were analyzed for soil texture, $\mathrm{pH}, \mathrm{EC}, \mathrm{N}, \mathrm{P}, \mathrm{K}, \mathrm{Ca}, \mathrm{Mn}$ and $\mathrm{Fe}$ [11]. The remaining soil samples were used to isolate AM fungal spore populations and Trichoderma species.

\section{Identification and mass production of AMF}

Spore population density and species richness of AMF from each soil sample was estimated by the method of wet sieving and decanting [12]. Assessment and the percentage of AMF colonization in the roots of onion were determined by the method of trypan blue in lactophenol [10]. For identification of AMF, intact spores were picked up from the filter paper and mounted on micro slides in lactophenol, and were observed under binocular research microscope. The morphology of spores and sporocarps of AMF were observed, and then their characters were used for identification by using Manual for identification of AM fungi [13]. Mass inoculum production of AMF was carried out in the roots of Sorghum vulgare Pers. under glass house condition, by the method of Selvaraj et al. [14]. The selected dominant six species of AMF viz., Acaulospora scrobiculata, Glomus aggregatum, G. fasciculatum,
G. deserticola, Gigaspora margarita and Scutellospora heterogama collected from four different study sites were only mass multiplied. Among them, Glomus aggregatum was selected for the efficient strain for further experimental use.

\section{Identification and mass multiplication of Trichoderma spp.}

Trichoderma species were isolated from rhizosphere soils of four different onion cultivated fields of West Showa, Ethiopia, using standard serial dilution plating technique on Trichoderma Selective Agar (TSA) medium [15], and identified down to species level based on standard mycological methods, with the help of the Manual of Soil Fungi [16], and the manual of Hypomycetes and identification of Trichoderma species [17]. Mass multiplication of Trichoderma species was followed by the method of Gopinathan and Selvaraj [18].

\section{In-vitro evaluation}

The pathogen, S. cepivorum, was isolated from bulbs of infected onion plants grown in well developed sick plot at APPRC, Ambo, and showing typical symptoms of the disease [19]. The isolated pathogen and the Trichoderma species were maintained as pure cultures at $4^{\circ} \mathrm{C}$ in refrigerator, until used. Twenty isolates with five species of Trichoderma were evaluated in-vitro for their antagonistic and inhibition potential against the onion white rot, using dual culture technique with direct confrontation test. Each of the twenty Trichoderma isolates and S. cepivorum were inoculated on to PDA (Potato Dextrose Agar) medium separately, and incubated at $25^{\circ} \mathrm{C}$ for 5 days. Control plates of the pathogen and the antagonist were also prepared. A Completely Randomized Design (CRD) was used. Isolates were then scored for degree of antagonism after five days, using the rating system of Bell et al. [20], on a scale of $1-5$, where class $1=$ Trichoderma completely overgrow the pathogen and cover the entire medium surface; class $2=$ Trichoderma overgrow at least $2 / 3$ of the medium surface; class $3=$ Trichoderma and Sclerotium each colonize $50 \%$ of the medium surface, and neither of them appear to dominate the other; class $4=$ Sclerotium colonizes at least two-thirds of the medium surface, and appear to withstand encroachment by Trichoderma, and class $5=$ Sclerotium completely overgrow the entire medium surface. According to this rating system, a Trichoderma isolate is considered as antagonistic, if the mean score was less or equal to class 2 and not antagonist if the number was greater than class 2. Another set of experiment was prepared for inhibition and colony growth tests. To determine the inhibition percentage of the pathogen by each of the tested antagonists, growth of S. cepivorum was recorded by measuring the diameter of the colonies. Percentage inhibition (I\%) of its colony growth was then calculated using the following formula used by Whipps [21].

$$
\mathrm{I} \%=\frac{(1-\text { average diameter of the Treated })}{\text { Average diameter of the Control }} \times 100
$$

Where I(\%) represents the average inhibition percentage; Treated indicates the average colony diameter of $S$. cepivorum in the presence of the antagonist, and Control is the average colony diameter of $S$. cepivorum without the antagonist.

\section{Efficacy test in vivo}

The experiment was conducted under glass house condition (12$15^{\circ} \mathrm{C}$ minimum and $26-30^{\circ} \mathrm{C}$ maximum temperature), at APPRC, Ambo, Ethiopia. The potential native AMF, G. aggregatum (Awaro isolate) and four species of Trichoderma isolates were evaluated for the biological control of white rot disease in onion, under pot culture condition [22]. Sterilized sand, decomposed animal dung, and sterilized 
sandy clay loam soil (1:1:2 ratio) (5 kg per pot) was used. Sclerotia of S. cepivorum was thoroughly mixed with surface soil (100 sclerotia per pot) and wheat bran: sand cultures of Trichoderma spp. (1 g/100 g soil) and AMF inoculum (50g/pot) were added to each pot, and thoroughly mixed with surface soil. Two onion seedlings (Variety Adama red) were planted in each pot. The experiment was laid out in Completely Randomized Design (CRD), with four replications and 12 treatments consisting of various combinations of G. aggregatum, and different isolates of Trichoderma spp. with S. cepivorum were maintained in pot culture. Uninoculated and inoculated with S. cepivorum alone were used as control check.

The following treatments were:

- Control (without Sclerotium cepivorum, AMF, and Trichoderma spp.)

- Control (Sclerotium cepivorum (Sc) alone),

- Glomus aggregatum (Ga) alone

- $\mathrm{Sc}+\mathrm{Ga}$

- $S c+T$. harzianum ATh1 isolate

- Sc+T. koningii QTk2 isolate

- Sc+T. hamatum NThm3 isolate

- Sc+T. viride ATv1 isolate

- $\mathrm{Sc}+\mathrm{Ga}+\mathrm{ATh} 1$ isolate

- $\mathrm{Sc}+\mathrm{Ga}+\mathrm{QTk} 2$ isolate

- $\mathrm{Sc}+\mathrm{Ga}+\mathrm{NThm} 3$ isolate

- $\mathrm{Sc}+\mathrm{Ga}+\mathrm{ATv} 1$ isolate

\section{Data analysis}

After 90 days of inoculation, the plants were uprooted and the data were recorded on plant height of healthy and diseased plants, shoot, root, and bulb dry biomass of plants, after drying the samples at $60^{\circ} \mathrm{C}$ to constant weight in a hot air oven. AMF root colonization and spore numbers in root zone soils were assessed by grid line intersection [10], and wet sieving and decantation methods [12], respectively. The per cent white rot infection was calculated using the following formula:

Per cent white rot infection=Total No. of diseased plants/Total No. of seedlings planted $\times 100$

The data were subjected to analysis of variance, and the treatment means were further separated by Duncan's Multiple Range Test (DMRT), for significant differences at the level of $\mathrm{P}>0.05 \%$.

\section{Results and Discussion}

\section{Edaphic characteristics}

Edaphic characteristics of the soils of the study areas indicated that the changes in soil moisture ranged from 9.2-10.5\%, were in accordance with the climatic changes during different seasons, and the soil $\mathrm{pH}$ was acidic ( $\mathrm{pH}$ 6.4-6.8) in all the four study sites, with low to moderate electrical conductivity (EC 1.4-1.8). The soil types were black sandy clay loam in Awaro, Qora and Nagafile sites, whereas dark grey clay loam in I/D Ajo. Generally, the soils were nutrient deficient, particularly high organic carbon (1.95-2.95\%), less P-level (2.2-2.8 mg/ $\mathrm{kg})$, moderate to high level of $\mathrm{K}(296-346 \mathrm{mg} / \mathrm{kg})$, and also with other micronutrient content such as zinc $(1.4-2.2 \mathrm{~g} / \mathrm{g})$, calcium $(1.2-1.8 \mathrm{~g} / \mathrm{g})$, manganese $(2.8-3.4 \mathrm{~g} / \mathrm{g})$, and iron $(58.5-98.5 \mathrm{~g} / \mathrm{g})$. The available $\mathrm{N}$ content of the soils, irrespective of the study sites, were invariably high $(625-860 \mathrm{mg} / \mathrm{kg})$

\section{AMF colonization}

The test plant was positive for AMF colonization in the roots of onion, although the species of AMF colonizing the organism was varied. Percent colonization of AMF in the roots of onion differed in each locality. But there was a definite trend in AMF colonization between the different characteristics of the soil. There was a certain degree of specificity among the different AMF species in those four study sites (Table 1). The presence of high degree of AM colonization with various AMF structures, such as infection pegs, hyphal coils (pelotons), hyphal dimorphism, intracellular arbuscules, inter and intracellular vesicles, were observed in the root cortical cells of onion. Rajeshkumar and Selvaraj [23] kept in mind while describing a species as mycorrhizal, if roots contained one of the following combinations of AM fungal structures in the primary cortex, hyphae+arbuscules, hyphae+pelotons, or hyphae+vesicles. Totally, ten AM fungal species were isolated from rhizosphere soils of the onion (Table 2). Of the ten AMF, only two species, G. aggregatum and G. fasciculatum, were found to be colonized in the roots of onion. The difference in colonization could be due to variation in the species and the soil type, upholding the view expressed by Schenck and Kinlock [24].

\section{Spores and sporocarps of AMF}

Altogether, ten AMF species representing four genera viz., Acaulospora, Gigaspora, Glomus, and Scutellospora were recorded (Table 2), of which Glomus was the dominant genus. Based on the frequency of occurrence, the AMF species were identified and grouped as dominant (above 50\%), and common (blow 50\%) forms. Accordingly, Gigaspora margarita. Glomus aggregatum, G. deserticola, G. fasciculatum, Acaulospora scrobiculata and Scutellospora heterogama, were dominant forms, whereas A. delegata, G. geosporum, G. macrocarpum and S. calospora were constitute common forms

\begin{tabular}{|l|c|c|c|l|}
\hline Location & $\begin{array}{c}\text { Percent AMF root } \\
\text { colonization }\end{array}$ & $\begin{array}{c}\text { Total No. of AMF } \\
\text { spores/100 g of soil }\end{array}$ & $\begin{array}{l}\text { Positive for AMF in the } \\
\text { roots }\end{array}$ & Positive for AMF in the root zone soils \\
\hline S1-Awaro & $96.5 \mathrm{a}$ & $1085 \mathrm{a}$ & Glomus aggregatum & $\begin{array}{l}\text { Glomus aggregatum, G. deserticola, Acaulospora delegata, A. } \\
\text { scrobiculata, Gigaspora margarita. }\end{array}$ \\
\hline S2-Qora & $84.5 \mathrm{~b}$ & $986 \mathrm{~b}$ & $\begin{array}{l}\text { Glomus aggregatum, G. fasciculatum, Acaulospora scrobiculata, } \\
\text { G. margarita }\end{array}$ \\
\hline S3-Nagafile & $56.5 \mathrm{c}$ & $425 \mathrm{c}$ & Glomus fasciculatum & $\begin{array}{l}\text { G.aggregatum, G. fasciculatum, G. geosporum, G. macrocarpum, } \\
\text { G. margarita, Scutellospora heterogama. }\end{array}$ \\
\hline S4-I/D Ajo & $32.6 \mathrm{~d}$ & $154 \mathrm{~d}$ & Glomus fasciculatum & $\begin{array}{l}\text { Glomus aggregatum, G. fasciculatum, G. margarita, S. calospora, } \\
\text { S. heterogama. }\end{array}$ \\
\hline
\end{tabular}

Means in the same column followed by the same superscript letter do not differ significantly, according to DMRT $(P<0.01)$.

Table 1: Colonization and spore density of AMF from rhizosphere soils of onion. 
Citation: Leta A, Selvaraj T, (2013) Evaluation of Arbuscular Mycorrhizal Fungi and Trichoderma Species for the Control of Onion White Rot (Sclerotium cepivorum Berk). J Plant Pathol Microb 4: 159. doi:10.4172/2157-7471.1000159

Page 4 of 6

\begin{tabular}{|l|c|c|c|c|c|}
\hline List of AMF & S1* $^{*}$ & S2 & S3 & S4 & $\begin{array}{c}\text { Species } \\
\text { frequency \% }\end{array}$ \\
\hline Acaulospora delegata & + & -- & -- & -- & 25 \\
\hline A. scrobiculata & + & + & -- & -- & 50 \\
\hline Gigaspora margarita & + & + & + & + & 100 \\
\hline Glomus aggregatum & + & + & + & + & 100 \\
\hline G. deserticola & + & + & - & - & 50 \\
\hline G. fasciculatum & -- & + & + & + & 75 \\
\hline G. geosporum & -- & -- & + & -- & 25 \\
\hline G. macrocarpum & - & -- & + & -- & 25 \\
\hline Scutellospora calospora & -- & -- & -- & + & 25 \\
\hline S. heterogama & -- & -- & + & + & 50 \\
\hline
\end{tabular}

*Study sites- S1-Awaro; S2-Qora; S3-Nagafile ; S4-I/D Ajo.

Table 2: Occurrence of AMF from rhizosphere soils of onion.

\begin{tabular}{|l|l|l|l|l|}
\hline Inoculation treatment & $\begin{array}{l}\text { Plant height } \\
\text { (Shoot and } \\
\text { root length) } \\
\text { (cm) }\end{array}$ & $\begin{array}{l}\text { Plant (Shoot } \\
\text { and root) } \\
\text { biomass } \\
\text { plant) }\end{array}$ & $\begin{array}{l}\text { \% AMF root } \\
\text { colonization }\end{array}$ & $\begin{array}{l}\text { No. of AMF } \\
\text { spores/100 } \\
\text { g soil }\end{array}$ \\
\hline Un inoculated control & $85.0 \mathrm{~d}$ & $24.90 \mathrm{~d}$ & $0.00 \mathrm{e}$ & $0.00 \mathrm{e}$ \\
\hline Acaulospora scrobiculata & $94.1 \mathrm{c}$ & $26.68 \mathrm{c}$ & $62.6 \mathrm{~d}$ & $486.00 \mathrm{c}$ \\
\hline Glomus aggregatum & $106.4 \mathrm{a}$ & $35.53 \mathrm{a}$ & $94.8 \mathrm{a}$ & $878.00 \mathrm{a}$ \\
\hline Glomus fasciculatum & $98.9 \mathrm{~b}$ & $30.88 \mathrm{~b}$ & $72.2 \mathrm{~b}$ & $568.00 \mathrm{~b}$ \\
\hline Glomus deserticola & $96.8 \mathrm{~b}$ & $29.46 \mathrm{~b}$ & $68.4 \mathrm{~b}$ & $493.00 \mathrm{~b}$ \\
\hline Gigaspora margarita & $100.8 \mathrm{~b}$ & $32.69 \mathrm{~b}$ & $78.4 \mathrm{~b}$ & $596.00 \mathrm{~b}$ \\
\hline Scutellospora heterogama & $89.7 \mathrm{c}$ & $26.99 \mathrm{c}$ & $58.5 \mathrm{c}$ & $345.00 \mathrm{~d}$ \\
\hline SEM & 2.8 & 1.4 & 2.8 & 14.6 \\
\hline CD (P<0.05) & 1.2 & 0.8 & 1.2 & 7.4 \\
\hline
\end{tabular}

Means in the same column followed by the same superscript letter do not differ significantly, according to DMRT $(P<0.01)$

Table 3: Effect of AMF on plant growth of S. vulgare.

(Table 2). The variation in spore population in onion also might be due to soil types. Higher number of AMF species was observed in black sandy clay loam soil study sites. The mean spore number per $100 \mathrm{~g}$ of soil varied from 365-1085 in root zone soils of onion. The lowest number of spores was recorded in root zone soil of onion (365/100 g) at I/D Ajo study site, whereas the highest number (1085/100 g) was observed in Awaro study site (Table 2). The AMF spore abundance was reported to be determined by the host plant species and environmental variables, than by AMF species [25]. Edaphic characteristics such as soil type [26], soil depth, soil $\mathrm{pH}$ [27], and soil fertility [28], were reported to influence AMF sporulation. The present study clearly highlights the soil edaphic factors that favor root colonization and sporulation of AMF, associated with onion crop. Rajeshkumar and Selvaraj [23] studied that AMF distribution is dependent on the host plant and certain ecological factors, such as organic carbon, soil $\mathrm{pH}$, soil nutrients, and soil fertility. Although AMF is not host specific, they exhibit certain host preferences [29]. Also, the root colonization patterns may regulated by the host. McGonigle and Fitter [30] reported from the study of two native grasses and forbs in England, that AMF in the field showed a degree of ecological specificity.

\section{Mass production of AMF}

Plants inoculated with $G$. aggregatum had significantly higher percent root colonization, extra-matrical spore count, shoot and root length, and shoot and root biomass (Table 3). Gigaspora margarita and G. fasciculatum were found to be the second best, next to $G$. aggregatum. All the parameters were found to be significantly least in plants inoculated with Scutellospora heterogama and A. scrobiculata.

\section{Isolation of $S$. cepivorum from diseased bulbs}

Fluffy white cottony growth of the fungal mycelium was noticed on the surface of the medium. As the growth of the mycelium progresses, the mycelium becomes more compacted with numerous small spherical black bodies (Sclerotia), forming on this mycelial mat, which are approximately the size of a poppy seed or pinhead.

\section{Mass multiplication of Trichoderma spp.}

Twenty isolates of Trichoderma spp. were isolated from rhizosphere soil samples of Ambo and Toke Kutaye districts study sites. Isolates were numbered based on substrate from which they were isolated (Table 4). The five species of Trichoderma viz., T. harzianum, T. viride, T. virens, T. koningii and T. hamatum were identified. The species identities of all the isolates are still under determination. The isolates were mass multiplied on wheat bran and sand substrate. As reported by Singh et al. [31], wheat bran as the good substrate used for multiplication of the Trichoderma antagonists.

\section{In vitro evaluation}

The mean colony growth of $S$. cepivorum in plates containing Trichoderma isolates ranged from $2.0 \mathrm{~cm}$ (T. harzianum) to $3.45 \mathrm{~cm}$ (T. virens). The antagonism test revealed that four of the twenty isolates

\begin{tabular}{|c|c|c|}
\hline Test organisms & $\begin{array}{l}\text { Mean colony growth of } \\
\text { S. cepivorum }(\mathrm{cm}) \text { and } \\
\text { Trichoderma species }\end{array}$ & $\begin{array}{c}\text { Mean } \\
\% \text { inhibition on } \\
\text { S. cepivorum }\end{array}$ \\
\hline $\begin{array}{l}\text { T. harzianum } \\
\text { ATh1 } \\
\text { QTh2 } \\
\text { NTh3 } \\
\text { ITh4 } \\
\text { Sclerotium } \\
\text { cepivorum(Control) }\end{array}$ & $\begin{array}{l}2.00 \mathrm{~d} \\
2.10 \mathrm{~d} \\
2.15 \mathrm{~d} \\
2.25 \mathrm{~d} \\
4.45 \mathrm{a}\end{array}$ & $\begin{array}{c}65.4 \mathrm{a} \\
64.8 \mathrm{a} \\
61.4 \mathrm{a} \\
60.8 \mathrm{a} \\
----\end{array}$ \\
\hline $\begin{array}{l}\text { T. viride } \\
\text { ATv1 } \\
\text { QTv2 } \\
\text { NTv3 } \\
\text { ITv4 } \\
\text { Sclerotium cepivorum } \\
\text { (Control) }\end{array}$ & $\begin{array}{l}2.10 \mathrm{~d} \\
2.35 \mathrm{c} \\
2.43 \mathrm{c} \\
2.54 \mathrm{~b} \\
4.45 \mathrm{a}\end{array}$ & $\begin{array}{c}64.8 \mathrm{a} \\
54.3 \mathrm{~b} \\
48.6 \mathrm{c} \\
43.6 \mathrm{c} \\
----\end{array}$ \\
\hline $\begin{array}{l}\text { T. hamatum } \\
\text { AThm1 } \\
\text { QThm2 } \\
\text { NThm3 } \\
\text { IThm4 } \\
\text { Sclerotium } \\
\text { cepivorum(Control) }\end{array}$ & $\begin{array}{l}2.34 \mathrm{c} \\
2.43 \mathrm{c} \\
2.48 \mathrm{c} \\
2.56 \mathrm{~b} \\
4.45 \mathrm{a}\end{array}$ & $\begin{array}{c}54.3 \mathrm{~b} \\
48.6 \mathrm{c} \\
45.4 \mathrm{c} \\
43.5 \mathrm{c} \\
----\end{array}$ \\
\hline $\begin{array}{l}\text { T. koningii } \\
\text { ATk1 } \\
\text { QTk2 } \\
\text { NTk3 } \\
\text { ITk4 } \\
\text { Sclerotium cepivorum } \\
\text { (Control) }\end{array}$ & $\begin{array}{l}2.38 \mathrm{c} \\
2.39 \mathrm{c} \\
2.56 \mathrm{~b} \\
2.45 \mathrm{c} \\
4.45 \mathrm{a}\end{array}$ & $\begin{array}{c}53.5 b \\
53.2 b \\
43.5 c \\
48.5 c \\
---\end{array}$ \\
\hline $\begin{array}{l}\text { T. virens } \\
\text { ATvn1 } \\
\text { QTvn2 } \\
\text { NTvn3 } \\
\text { ITvn4 } \\
\text { Sclerotium cepivorum } \\
\text { (Control) }\end{array}$ & $\begin{array}{l}3.15 \mathrm{a} \\
3.24 \mathrm{a} \\
3.45 \mathrm{a} \\
3.23 \mathrm{a} \\
4.45 \mathrm{a}\end{array}$ & $\begin{array}{c}35.6 \mathrm{~d} \\
33.8 \mathrm{~d} \\
32.5 \mathrm{~d} \\
33.5 \mathrm{~d} \\
----\end{array}$ \\
\hline C.V. & 7.66 & 12.4 \\
\hline LSD (0.01) & 0.48 & 8.2 \\
\hline SE & 0.14 & 2.2 \\
\hline
\end{tabular}

Means in the same column followed by the same superscript letter do not differ significantly, according to DMRT $(P<0.01)$.

Table 4: Interaction between S. cepivorum and Trichoderma species under in vitro. 
which were scored less than 2 were highly antagonistic to the white rot pathogen. However, T. virens, which exhibited a score of 3.15-3.45, was not antagonistic at all. This isolate grew only up to $1 \mathrm{~cm}$ in 5 days, indicating that it was not antagonistic, whereas all the other isolates colonized and covered the colonies of $S$. cepivorum on the respective plates. This isolate was, therefore, not tested further. In contrast, its colony growth reached $4.45 \mathrm{~cm}$ after 7 days in control plates. The results of the data recorded 5-7 days after inoculation showed that there was a significant difference among the Trichoderma species, in suppressing the colony growth of the pathogen and inhibition percentage (Table 4). T. harzianum ATh1 isolate covered the plate completely on the $5^{\text {th }}$ day incubation, while the other species grew and cover the plate on the $6^{\text {th }}$ day of incubation. Meanwhile, in the control treatment, S. cepivorum grown, covered the plates on the $7^{\text {th }}$ day of inoculation and producing sclerotia after the $10^{\text {th }}$ day. Therefore, $S$. cepivorum did not grow at all when inoculated after 48 hours inoculation of Trichoderma species. Trichoderma isolates are known to rapidly colonize medium surface and substrates [32]. Trichoderma harzianum inhibited the colony growth of S. cepivorum by $65.4 \%$, followed by T. viride (64.8\%), T. hamatum (54.3\%), and T. koningii (53.5\%, which was also significantly different from each other. Akrami et al. [33] also found that T. asperillum and T. harzianum reduced $43.2 \%$ and $51.5 \%$ reduction in disease incidence, respectively. Up to $36 \%$ reduction of colony growth of $F$. oxysporum was obtained by using Trichoderma harzianum isolate [34]. In a similar study done by using culture filtrates of T. viride, Tesfaye [35] found that F. solani could grow only for $1.5 \mathrm{~mm}$ in $96 \mathrm{hrs}$ (4 days). Alemu and Kapoor [36] also found that T. viride and T. harzianum inhibited the fungus, Botrytis gladiolorium that causes corm rot on Gladiolus. Antagonistic interactions of Trichoderma species with other fungi and mechanisms involved in the bio-control process are based on antibiosis, parasitism, induced resistance and competition [37], and also produced enzymes that have been proved to be involved in the antagonistic activity [38]. However, antagonistic fungi are specific in their antagonistic activity against specific fungi [39]. In vitro tests are suitable for selecting antagonistic organisms with a particular mode of action, but are very poor predictors of the activity of the organisms in the field [40]. According to Mpika et al. [41], efficiency of Trichoderma species in antagonizing plant pathogens is closely linked with local conditions. Arya and Kaushik [42] reported maximum inhibition of Fusarium oxysporum and Rhizotonia solani (74.7-75.2\%), with
Gliocladium virens, followed by T. harzianum (65.9-72.4\%). Kapoor [43] reported that the maximum inhibition growth by T. harzianum against R. solani, Pythium debayanum, Sclerotinia minor and Fusarium oxysporum f.sp .pisi. In the present study also, T. harzianum ATh1 isolate showed maximum inhibition of S. cepivorum (65.4\%).

\section{In vivo evaluation}

Inoculation with Glomus aggregatum alone increased the plant growth parameters to the maximum, while less plant growth was observed in the plants inoculated with $S$. cepivorum alone. In all treatments, G. aggregatum either alone or in combination with isolates of Trichoderma spp. and pathogen, showed significant growth response and reduced the disease incidence, when compared to un inoculated and S. cepivorum alone control plants (Table 5). G. aggregatum combination with T. harzianum ATh1 isolate was significantly increased the growth, biomass, and reduced the disease incidence and severity of white rot disease in onion plants caused by $S$. cepivorum. The overall reduction in the incidence of white rot was $66.19 \%$ for G. aggregatum, with $T$. harzianum ATh1 isolate. The lowest shoot, root and bulb dry weights were recorded in plants inoculated with $S$. cepivorum alone. Singh et al. [31] reported that native species of Trichoderma was controlled red rot of sugarcane by the enzymatic action of the metabolites released by bio-agent. Some workers also showed that AMF can also be used as biological deterrent of soil borne diseases of vegetable crops $[7,18]$. In the present study, the wheat bran: sand formulation of T. harzianum ATh1 isolate combined with inoculum of G. aggregatum, significantly reduced the white rot of onion caused by $S$. cepivorum.

\section{Conclusion}

From the results of this study, it is concluded that the tested indigenous Trichoderma isolates have high potential to inhibit the colony growth of $S$. cepivorum. The efficacy test results of AMF and Trichoderma spp. clearly indicates that AM fungal inoculation alone, or in combination with Trichoderma spp. reduced the incidence and severity of white rot, and increased the plant growth of onion. Also, these two bio-control agents commercially exploited as bio-fungicides, and could be recommended to the farmers in Western Showa, Ethiopia for the management of white rot in onion. The outcome of biofungicides (Trichoderma and AMF) distribution under the lab to land

\begin{tabular}{|c|c|c|c|c|c|}
\hline Treatments & $\begin{array}{l}\text { Average height of } \\
\text { healthy plants }(\mathrm{cm})\end{array}$ & $\begin{array}{l}\text { Average height of } \\
\text { diseased plants }(\mathrm{cm})\end{array}$ & $\begin{array}{l}\text { Shoot and root dry } \\
\text { weight of healthy } \\
\text { plants (g/plant) }\end{array}$ & $\begin{array}{c}\text { Average bulb weight of } \\
\text { healthy plants }\end{array}$ & $\begin{array}{c}\text { Per cent root rot } \\
\text { incidence and severity* }\end{array}$ \\
\hline Control ( without inoculants) & $62.0 \mathrm{~b}$ & ---- & $6.98 \mathrm{~b}$ & $12.4 \mathrm{~b}$ & ---- \\
\hline $\begin{array}{l}\text { Control check (Sclerotium cepivorum (Sc) } \\
\text { alone) }\end{array}$ & $24.5 \mathrm{a}$ & $12.5 \mathrm{a}$ & $1.24 \mathrm{a}$ & $6.8 \mathrm{a}$ & $90.5(50.84) \mathrm{a}$ \\
\hline Glomus aggregatum $(\mathrm{Ga})$ alone & $68.8 \mathrm{e}$ & ---- & 9.88 e & $20.8 \mathrm{e}$ & ---- \\
\hline $\mathrm{Sc}+\mathrm{Ga}$ & $64.4 \mathrm{~d}$ & $46.5 \mathrm{c}$ & $8.76 \mathrm{~d}$ & $17.6 \mathrm{~d}$ & $46.28(21.62) c$ \\
\hline Sc+Trichoderma harzianum (ATh1 isolate) & $68.2 \mathrm{e}$ & $48.8 \mathrm{c}$ & $9.85 \mathrm{e}$ & $18.2 \mathrm{~d}$ & 43.78(13.97)c \\
\hline $\mathrm{Sc}+T$. koningii (QTk2 isolate) & $60.5 \mathrm{c}$ & $34.7 \mathrm{~b}$ & $7.82 \mathrm{c}$ & $16.5 \mathrm{c}$ & $45.03(23.11) c$ \\
\hline $\mathrm{Sc}+T$. hamatum (NThm3 isolate) & $59.6 \mathrm{c}$ & $32.6 \mathrm{~b}$ & $7.45 \mathrm{c}$ & $16.4 \mathrm{c}$ & $56.25(35.74) b$ \\
\hline Sc+T. viride (ATv1 isolate) & $66.5 \mathrm{e}$ & $46.8 \mathrm{c}$ & $8.45 d$ & $17.8 d$ & $39 . .65(14.68) d$ \\
\hline $\mathrm{Sc}+\mathrm{Ga}+\mathrm{ATh} 1$ isolate & $69.5 \mathrm{e}$ & $52.4 \mathrm{~d}$ & $9.95 \mathrm{e}$ & $21.2 \mathrm{f}$ & 33.81(11.31)e \\
\hline $\mathrm{Sc}+\mathrm{Ga}+\mathrm{QTk} 2$ isolate & $66.8 \mathrm{e}$ & $49.6 \mathrm{~d}$ & $8.24 \mathrm{~d}$ & $20.3 \mathrm{e}$ & $45.03(19.5) c$ \\
\hline $\mathrm{Sc}+\mathrm{Ga}+\mathrm{NThm} 3$ isolate & $64.5 \mathrm{~d}$ & $40.6 \mathrm{c}$ & $8.75 \mathrm{~d}$ & $19.8 \mathrm{e}$ & $56.28(23.11) b$ \\
\hline $\mathrm{Sc}+\mathrm{Ga}+\mathrm{AT}$ 1 1 isolate & $67.5 \mathrm{e}$ & $50.8 d$ & $8.65 d$ & $20.6 \mathrm{e}$ & $40.25(20.56) d$ \\
\hline LSD 0.01 & 8.6 & 6.8 & 1.4 & 3.4 & 8.6 \\
\hline CD (\%) & 2.4 & 3.4 & 0.4 & 0.8 & 2.4 \\
\hline
\end{tabular}

*Percent severity-the data in parenthesis.

Means in the same column followed by the same superscript letter do not differ significantly, according to DMRT ( $P<0.01)$.

Table 5: Effect of Glomus aggregatum and Trichoderma spp. on growth and the incidence of onion white rot. 
Citation: Leta A, Selvaraj T, (2013) Evaluation of Arbuscular Mycorrhizal Fungi and Trichoderma Species for the Control of Onion White Rot (Sclerotium cepivorum Berk). J Plant Pathol Microb 4: 159. doi:10.4172/2157-7471.1000159

program has clearly brought out the role of AMF and Trichoderma spp. in the management of plant disease in field conditions, at Western Showa, Ethiopia, which merit commercialization.

\section{Acknowledgements}

I am greatly indebted to my advisor Prof. Thangavel Selvaraj for his invaluable professional help, initiatives and encouragement. This research work also could have been realized without the consistent support of the whole staff of Ambo Plan Protection Research Center (APPRC) and Department of Plant Sciences of Ambo University, Ambo, Ethiopia

\section{References}

1. Griffiths G, Trueman L, Crowther T, Thomas B, Smith B (2002) Onions: A global benefit to health. Phytother Res 16: 603-615.

2. Krest I, Keusgen M (1999) Quality of herbal remedies from Allium sativum differences between allinase from garlic powder and fresh garlic. Planta Med 65: $139-143$

3. Steinmetz KA, Potter JD (1996) Vegetables, fruits and cancer prevention: a review. J Am Diet Assoc 96: 1027-1039.

4. Tabor G, Zeleke A (2000) Achievements in Shallot and Garlic Research. EARO Research Report, Addis Abeba, Ethiopia.

5. Tesfaye B (2006) Diseases of vegetables in Ethiopia. Plant Protection Research Center, Ambo, Ethiopia

6. Trotta A, Varese GC, Gnavi E, Fusconi A, Sampo S, et al. (1996) Interaction between the soil borne root pathogen Phytophthora nicotianae var. parasitica and the Arbuscular mycorrhizal fungus, Glomus mosseae in tomato plants. Plant Soil 185: 199-209.

7. Hooker JE, Gianinazzi S, Vest berg M, Barea JM, Atkinson D (1994) The application of arbuscular mycorrhizal fungi to micro propagation systems: an opportunity to reduce chemical inputs. Agricultural Sciences of Finland 3: 227 232

8. Linderman RG (1994) Role of VAM fungi in the bio control. In: Pfleger FL, Linderman RG (eds.), Mycorrhizae and Plant Health. APS Press, St. Paul, USA.

9. Weindling R (1932) Trichoderma lignorum as a parasite of other soil fungi. Phytopathology 22: 837-845.

10. Phillips JF, Hayman DS (1970) Improved procedures for clearing roots and staining parasite and vesicular arbuscular mycorrhizal fungi for rapid assessment of infection. Transactions of British Mycological Society 55: 158-

11. Jackson ML (1973) Soil Chemical Analyses. Prentice Hall, New Delhi, India.

12. Gerdemann JW, Nicolson TH (1963) Spores of mycorrhizal Endogone species extracted from soil by wet-sieving and decanting. Transactions of British Mycological Society 46: 235-244.

13. Schenck NC, Perez Y (1990) Manual for the Identification of Arbuscular Mycorrhizal Fungi. University of Florida, Gainesville, Florida, USA.

14. Selvaraj T, Nisha MC, Rajeshkumar S (2009) Effect of indigenous arbuscular mycorrhizal fungi on some growth parameters and phytochemical contituents of Pogostemon patchouli Pellet. Maejo Int J Sci Technol 3: 222-234.

15. Elad Y, Chet I (1983) Improved selective media for isolation of Trichoderma spp. or Fusarium spp. Phytoparasitica 11: 55-58.

16. Gilman JC (1957) A Manual of Soil fungi. ( $2^{\text {nd }}$ edition), Ames, IOWA, USA.

17. Rifai MA (1969) A Revision of the Genus Trichoderma. Mycological Papers, Herbarium Bogoriense, Bogor, Java, Indonesia.

18. Gopinathan M, Selvaraj T (2008) Effect of Glomus aggregatum in combination with Trichoderma viride against Macrophomina phaseolina in sesame. Indian Journal of Applied and Pure Biology 23: 49-54

19. Das BC, Dutta P, Devi G (2000) Management of Sclerotium rolfsii in tomato by fungal antagonists. Journal of the Agricultural Science Society of North Eas India 13: 101-103.

20. Bell DK, Wells HD, Markham CR (1982) In-vitro antagonism of Trichoderma spp. against six fungal plant pathogens. Phytopathology 72: 379-382.
21. Whipps JM (1987) Developments in the biological control of soil-borne plant pathogens. Adv Bot Res 26: 1-134.

22. Srivastava KJ, Qadri SMH, Tiwari BK, Bhonde SR, Pandey UB (1991) Control of purple blotch disease of onion bulb crop in kharif season. Indian Phytopathology 44: 251-253.

23. Rajeshkumar S, Selvaraj T (2006) Influence of native arbuscular mycorrhizal fungi on growth, nutrition and biomass production of tea var., UPASI-9. Indian Journal of Applied and Pure Biology 21: 31-38.

24. Schenck NC, Kinloch RA (1980) Incidence of mycorrhizal fungi on six field crops in monoculture on a newly cleared woodland site. Mycologia 72: 445-456.

25. Koske RE (1987) Distribution of VA mycorrhizal fungi along a latitudina temperature gradient. Mycologia 79: 55-68.

26. Joshi KC, Singh HP (1995) Inter-relationships among arbuscular mycorrhizae population, soil properties and root colonization capacity of soil. Journal of Indian Society and Soil Science 43: 204-207.

27. Gopinathan M, Selvaraj T (2007) Effects of soil depth and seasonal change on VA-mycorrhizal colonization and spore population in mulberry (Morus alba L.). Indian Journal of Applied and Pure Biology 22: 49-54.

28. Abbott LK, Robson AD (1991) Factors influencing the occurrence of vesiculararbuscular mycorrhizas. Agric Ecosyst Environ 35: 121-150.

29. Dhillion SS (1992) Evidence for host-mycorrhizal preference in native grassland species. Mycol Res 96: 359-362.

30. McGonigle TP, Fitter AH (1992) Ecological specificity of vesicular-arbuscular mycorrhizal associations. Mycol Res 94: 120-122.

31. Singh V, Srivastava SN, Lal RJ, Awasthi SK, Joshi BB (2008) Biologica control of red rot disease of sugarcane through Trichoderma harzianum and Trichoderma viride. Indian Phytopathology 61: 486-491.

32. Kucuk C, Kivanc M (2004) In-vitro antifungal activity of strains of Trichoderma harzianum. Turk J Biol 28: 111-115.

33. Akrami M, Ibrahimov ASh, Zafari DM, Valizadeh E (2009) Control of Fusarium rot of bean by combination of by Trichoderma harzianum and Trichoderma asperellum in greenhouse condition. Agricultural Journal 4: 121-123.

34. Sahi IY, Khalid AN (2007) In-vitro biological control of Fusarium oxysporum causing wilt in Capsicum annuum. Mycopath 5: 85-88.

35. Tesfaye B (1999) Evaluation of the potential of Trichoderma viride as biological control agent of root rot disease, Fusarium solani of faba bean. Pest Management Journal of Ethiopia 3: 91-94.

36. Alemu T, Kapoor IJ (2004) In-vitro evaluation of Trichoderma and Gliocladium spp. against Botrytis corm rot of Gladiolus. Pest Management Journal of Ethiopia 8: 97-103.

37. Hoitink HAJ, Stone AG, Han DY (1997) Suppression of plant diseases by compost. Horticultural Science 32: 184-187.

38. Howell CR (2003) Mechanisms employed by Trichoderma species in the biological control of plant diseases: the history and evolution of current concepts. Plant Dis 87: 4-10.

39. Saleem A, Hamid K, Tariq AH, Jamil FF (2000) Chemical control of root and collar rot of chillies. Pakistan Journal of Phytopathology 12: 1-5

40. Campbell R (1989) Biological Control of Microbial Plant Pathogens. Cambridge University Press, UK.

41. Mpika J, Kebe IB, Issali AE, N'Guessan FK, Druzhinina S, et al. (2009) Antagonist potential of Trichoderma indigenous isolates for biological contro of Phytophthora palmivora the causative agent of black pod disease on cocoa (Theobroma cacao L.) in Cote d'Ivoire. Afr J Biotechnol 8: 5280-5293.

42. Arya S, Kaushik JC (2001) Efficacy of Trichoderma species and Gliocladium virens as biocontrol agents against damping-off of forest nurseries. Plant Disease Research 16: 46-51.

43. Kapoor AS (2008) Biological potential of Trichoderma spp. against important soil borne diseases of vegetable crops. Indian Phytopathology 61: 492-498. 